\title{
US presidential candidates diverge on how to help biopharma
}

In the US presidential debates this month, incumbent Barack Obama and his rival Mitt Romney will be laying out opposing arguments about health care, tax cuts and strategies to fix the economy. Notably, they have differing remedies to rejuvenate the country's biopharmaceutical sector: Obama believes that bolstering government-funded research will extend America's edge in the field, whereas Romney believes that corporate tax breaks will encourage the companies to thrive. The question of who ends up in the White House next January is no small matter to US makers of brand-name medicines, which face tough decisions as a result of growing competition from producers of generics and foreign drug developers.

The US corporate tax rate is now 35\%the highest in the world-and analysts point to this as having hurt biopharmaceutical companies. Moreover, even though the US became the first country to instate tax credits for research and development (R\&D) in 1981, its incentives now fall behind those of 27 other countries. According to one estimate by the consulting firm Challenger, Gray \& Christmas, based in Chicago, pharmaceutical companies have lost a gross estimate of 300,000 US jobs since 2000. An overall decline in jobs within the sector has been partly caused by a "heavy wave of mergers and acquisitions," says John Challenger, chief executive of the firm.

During his time as governor of Massachusetts, Romney was known to court biopharmaceutical companies by offering them special tax incentives to encourage economic growth in his state. In his bid for the presidency, he has pledged to cut corporate tax rates to $25 \%$, which some hope will lower costs for companies and thereby incite growth. But it might not be so simple when it comes to biopharma, according to Erik Gordon, a health care and pharmaceutical industry economist at the University of Michigan-Ann Arbor. Biopharma companies are often willing to accept higher taxes if it means they have access to the largest number of highly trained people, and although the US has a significant edge in terms of the supply of individuals equipped to do research, other countries are training individuals in the area of product development faster than the US, Gordon says. If companies decide to leave in pursuit of these highly skilled people, Romney's lower US corporate taxes won't dissuade them, he warns. "We want to try to create
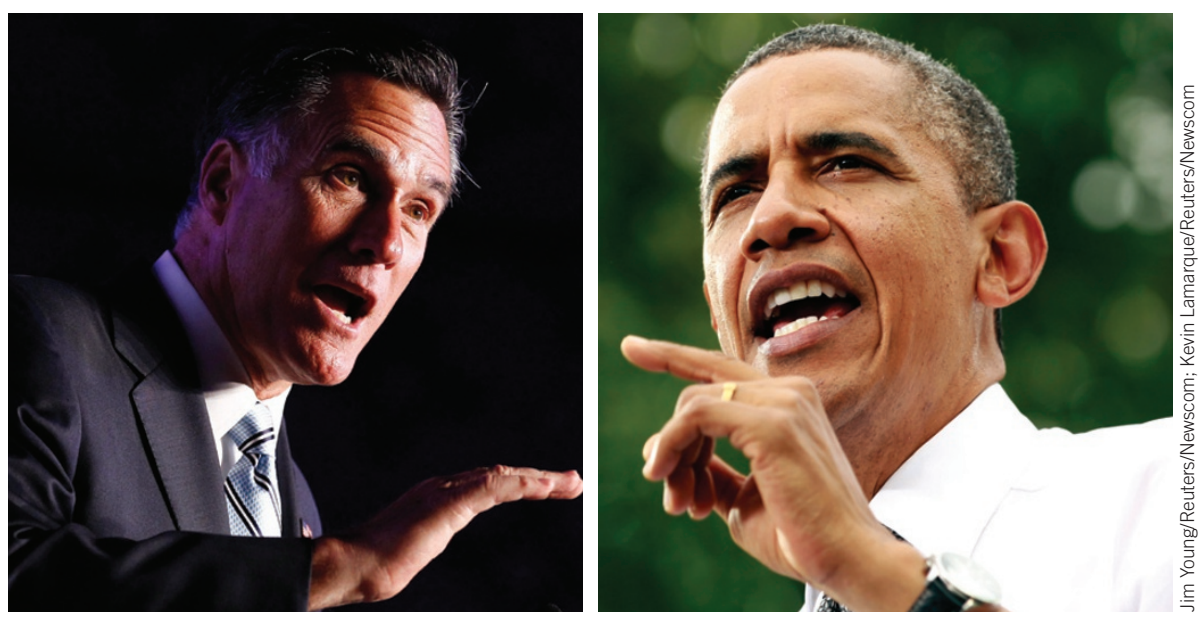

A tale of two tactics: Romney favors a corporate tax cut, whereas Obama leans toward investment.

an environment where drug companies can find the skilled workers that they need," Challenger says.

Ensuring continuous research and development funding is most important for drug companies, according to Ellie Dehoney, vice president of policy and programs with Research!America, an advocacy group based in Alexandria, Virginia that encourages government support of health research. In his 2013 budget, Obama proposed increasing research and development funding by $\$ 2$ billion, a $3.3 \%$ increase from the previous year. Romney has not been specific on numbers, but he plans to focus his R\&D funding on the country's Defense Advanced Research Projects Agency. Republican vice presidential candidate Paul Ryan has proposed a budget in which he cuts nondefense R\&D funding by $5 \%$ by 2013, although as Nature Medicine went to press Romney had not endorsed this plan. The campaigns of both candidates did not respond to requests from this journal for details about their plans to boost the biopharmaceutical sector.

\section{Race to the finish}

All analysts agree that a strong US Food and Drug Administration (FDA) - with adequate resources for approving new compounds-is essential for the drug industry. According to Challenger, it's Romney who is expected to "simplify regulation," helping drugs get on the fast track to approval. But other onlookers say that under Obama's presidency, the FDA has shown speed in giving new drugs the green light: in 2009 and 2011 the agency approved 37 and 35 new medicines, the highest two numbers in a single year in the past decade.

In certain aspects, Obama is seen as creating woes for brand-name drugmakers, as they will be hurt by his plan to limit the time drug research is protected under data exclusivity laws-which he hopes to cut from 12 to 7 years. This 12-year protection exists to guarantee a profitable return for companies who invest heavily in new medications. The industry group PhRMA, based in Washington, $\mathrm{DC}$, argues that the change might encourage companies to relocate their manufacturing facilities to foreign shores. (For its part, the Generic Pharmaceutical Association says that this reduction in the data exclusivity period would boost generics makers, which it says already supply $80 \%$ of Americans' drugs.)

Additionally, Obama's reelection would support the continuance of the Affordable Health Care Act, which relies in part on taxes on brand-name drug companies to fund health insurance coverage. This makes Obama "the scariest guy the [brand name] industry has faced for a long time," according to Gordon. On the flipside, the Republican urge to reduce government spending will include "cuts to Medicare and Medicaid that will [also] hurt the drug industry," says Dehoney.

Between a stale economy, the rise in generics and increased foreign competition, the US biopharmaceutical market is facing an uphill battle, Gordon says. "What a President Romney would face is the same thing a reelected President Obama would face, which is giant healthcare bills and something has to be done about them."

Susan Matthews 